\title{
Water management and crop coefficients for pot chrysanthemum
}

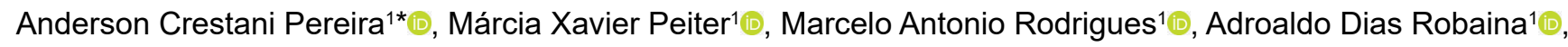

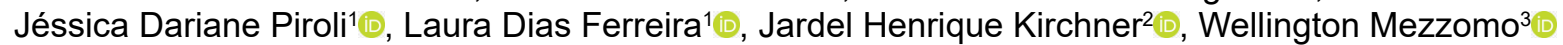

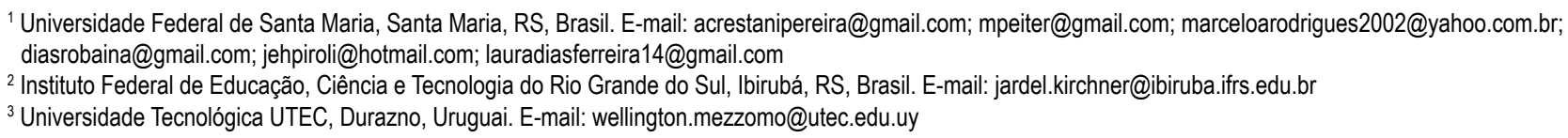

ABSTRACT: Chrysanthemum is one of the most commercialized flower species in Brazil, however, there is little information related to the correct water management of the crop. Thus, the work seeks to determine the crop evapotranspiration (ETC) and obtain the cultural coefficients (Kc) of the pot chrysanthemum, in addition to assessing the water use efficiency (EUA) of the crop under different irrigation managements. The experiment was conducted in a protected environment in Santa MariaRS, which a completely randomized design (DIC) was used, with five treatments based on the capacity of water retention in the vessel (CRV) $(40,60,80,100$ and $120 \%$ CRV), with 16 repetitions, each pot was considered one repetition. ETC was determined by weighing Lysymetry, ETo was calculated by six different equations: Benevides-Lopez, Camargo, Linacre, Jensen-Haise, Hargreaves and Ivanov. Kc was obtained by the relationship between ETc and ETo. The evapotranspiration of the culture ranged between 153 and $264 \mathrm{~mm}$. There was no significant difference in the EUA between the treatments studied. The average $\mathrm{Kc}$ was 0.98 for the vegetative phase, 1.29 from the beginning of the reproductive phase to the point of commercialization and 0.85 until the end of the reproductive phase.

Key words: Dendranthema grandiflorum; irrigation management; protected environment

\section{Manejo hídrico e coeficientes culturais para o crisântemo de vaso}

RESUMO: O crisântemo é uma das espécies florícolas mais comercializadas no Brasil, entretanto, há poucas informações relacionadas ao correto manejo hídrico da cultura. Desta forma, o trabalho busca determinar a evapotranspiração da cultura (ETc) e obter os coeficientes culturais (Kc) do crisântemo de vaso, além de avaliar a eficiência de uso da água (EUA) da cultura sob diferentes manejos de irrigação. $O$ experimento foi conduzido em ambiente protegido em Santa Maria-RS, no qual adotou-se o delineamento inteiramente casualizado (DIC), com cinco tratamentos baseados na capacidade de retenção de água no vaso (CRV) $(40,60,80,100$ e 120\% CRV), com 16 repetições, sendo cada vaso considerado uma repetição. A determinação da ETc se deu por lisimetria de pesagem, a ETo foi calculada por seis distintas equações: Benevides-Lopez, Camargo, Linacre, Jensen-Haise, Hargreaves e Ivanov. O Kc foi obtido pela relação entre a ETc e a ETo.A evapotranspiração da cultura oscilou entre 153 e $264 \mathrm{~mm}$. Não ocorreu diferença significativa de EUA entre os tratamentos estudados. O Kc médio foi de 0,98 para fase vegetativa, 1,29 do início da fase reprodutiva até o ponto de comercialização e 0,85 até o fim da fase reprodutiva.

Palavras-chave: Dendranthema grandiflorum; manejo da irrigação; ambiente protegido

\footnotetext{
*Anderson Crestani Pereira - E-mail: acrestanipereira@gmail.com (Corresponding author)

Associate Editor: Edna Maria Bonfim-Silva
} 


\section{Introduction}

Floriculture is a promising branch of Brazilian agribusiness and, the ornamental plants market, grew $64 \%$ between the years 2012 and 2018, for the year 2018 the ornamental market moved a total of $\mathrm{R} \$ \mathbf{7} 9$ billion in Brazil (Ibraflor, 2020). Whether as a cut flower or a vase flower, chrysanthemum (Dendranthema grandiflorum) is one of the most commercialized ornamental plant species in Brazil (Kelling et al., 2015).

Barbosa et al. (2019) consider chrysanthemum as the main ornamental species produced and commercialized in pots in Brazil, for being cultivated throughout the national territory, with diversified production technologies, for the offer of distinct varieties and for the cost/benefit of production. However, Spadeto (2016) highlights that little research has been developed with irrigated chrysanthemum culture.

The management of irrigation in floriculture has been characterized by empiricism, often with excessive or deficit applications of water. To avoid the risk of water deficit occurrence, many flower growers irrigate several times a day (Oliveira et al., 2016). For ornamental species, especially those grown under controlled conditions, information on water requirements and proper irrigation management is scarce (Soares et al., 2015).

Proper irrigation management is one of the most important factors to consider when seeking to improve flower production and quality, especially in a protected environment where water is made available only by irrigation (Soares et al., 2012; Girardi et al., 2016). The increase in quality is important, since in the flower industry the aesthetics of the plants influence the classification of the product and the maximization of the marketing profit.

Among the different parameters applicable for proper irrigation management is the estimation of reference evapotranspiration (ETo) (Andrade et al., 2016) and, also, the crop coefficient $(\mathrm{Kc})$ can be used to estimate the evapotranspiration of a crop (ETc) (Oliveira, 2012). However, currently in the scientific literature there is a description of Kc only for cut chrysanthemum. The pot chrysanthemum has lower water consumption compared to cut chrysanthemum and this is due to its smaller size and vegetative development. Thus, the adoption of the cultural coefficient of the cut chrysanthemum could lead to an irrigation management not adequate to the culture conducted in pots.

Under protected environment conditions there is a reduction of water requirements, due to the reduction of evapotranspiration, making more efficient use of water by the plants (Oliveira et al., 2014). With this, knowledge of crop evapotranspiration is a factor of great relevance in the sizing and management of irrigation systems (Oliveira et al., 2017), enabling the rational use of water and fertilizers, ensuring greater production efficiency and greater profitability.

In this context, the present work seeks to determine the evapotranspiration of the crop and to obtain the cultural coefficients of the pot chrysanthemum $(\mathrm{Kc})$, as well as to evaluate the water use efficiency of the pot chrysanthemum under different irrigation managements.

\section{Materials and Methods}

The work was developed in the Floriculture Sector of the Polytechnic College of the Universidade Federal de Santa Maria (UFSM), in the city of Santa Maria (29 $43^{\prime} \mathrm{S}$ and $49^{\circ} 19^{\prime} \mathrm{O}$ and with an altitude of $95 \mathrm{~m}$ ), located in the central region of the state of Rio Grande do Sul, Brazil.

The experiment was conducted in a protected environment with an area of $600 \mathrm{~m} 2(20 \times 30 \mathrm{~m}), 3.5$ meters high, and polyethylene cover (150 microns). The environment had a Pad Fan refrigeration system and hot air heating.

According to the Köppen classification, the region's climate is of type Cfa, humid subtropical, with hot summers and no defined dry season (Heldwein et al., 2009). The variation of the minimum and maximum temperature, as well as the relative humidity throughout the experiment is presented in Figure 1 . The average daily temperature ranged from 14.31 to $27.15{ }^{\circ} \mathrm{C}$, while the average relative humidity was $79.40 \%$.

In this work we used the chrysanthemum variety 'Cherry White', which has inflorescences of the mini daisy type with white coloration. The vegetative cuttings came previously treated by the Terra Viva company, located in Holambra, SP, Brazil, with the rooting hormone indol-butyric acid (AIB) at a concentration of $1.5 \mathrm{ppm}$.

The cuttings were transplanted into black plastic pots with a volume of $1.2 \mathrm{~L}$ (height $12 \mathrm{~cm}$, upper and lower base 14.0 and $9.4 \mathrm{~cm}$ in diameter) with drains at the lower end, filled with the commercial substrate Multiplant 3010.

In each pot, six vegetative cuttings were transplanted, remaining for four weeks in a rooting bed with controlled relative humidity and temperature conditions. After this period, the apical meristem was removed and the application of the different irrigation treatments was started.

Table 1 shows the physical and chemical characterization of the substrate used.

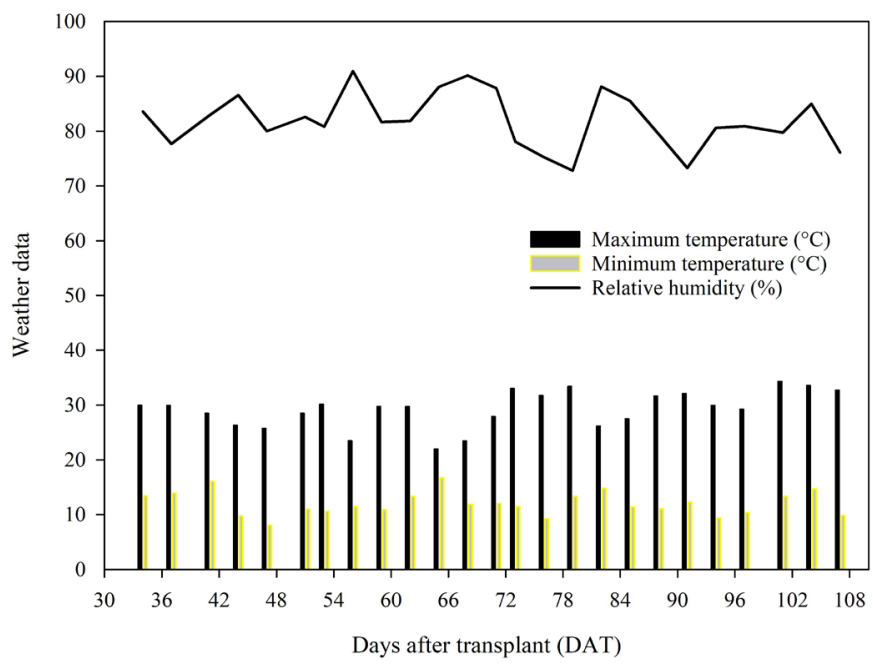

Figure 1. Temperature data (minimum and maximum) and average relative humidity for the experiment period. 
Table 1. Physical and chemical characteristics of Multi plant substrate 3010 used in the experiment.

\begin{tabular}{|c|c|c|c|c|c|c|c|c|}
\hline \multirow{2}{*}{$\begin{array}{c}\mathrm{pH} \\
\left(\mathrm{H}_{2} \mathrm{O}\right) \\
\end{array}$} & \multirow{2}{*}{$\begin{array}{c}\mathrm{EC} \\
\left(\mathrm{mS} \mathrm{cm}^{-1}\right) \\
\end{array}$} & EAW & BW & RW & \multirow{2}{*}{$\begin{array}{c}\text { Density (DD) } \\
\left(\mathrm{kg} \mathrm{m}^{-3}\right)\end{array}$} & TP & AS & AW \\
\hline & & & $(\%)$ & & & \multicolumn{3}{|c|}{$(\%)$} \\
\hline 6.15 & 0.80 & 15.16 & 2.43 & 36.31 & 319.79 & 90.42 & 36.52 & 17.59 \\
\hline
\end{tabular}

$\mathrm{pH}=$ determined in water, dilution 1:5 (v/v); EC = electrical conductivity obtained in 1:5 (v/v) solution; EAW = easily available water; BW = buffering water; RW = remaining water; DD = dry density; $\mathrm{TP}=$ total porosity; $\mathrm{AS}=$ aeration space; $\mathrm{AW}=$ available water.

According to Barbosa et al. (2019), in the establishment of chrysanthemum, soils or substrates with low density, rich in organic matter, with good drainage and nutrient availability are considered ideal. The $\mathrm{pH}$ value of the substrate is within the range of 5.5 to 6.5 recommended by the Commission of Chemistry and Soil Fertility of the states of Rio Grande do Sul and Santa Catarina (CQFS - RS/SC, 2016) for pot chrysanthemum cultivation, as well as, the electrical conductivity (EC) value of the substrate of 0.80 is in agreement with values recommended by Barbosa et al. (2019), which suggest that the substrate EC for pot chrysanthemum be between 0.7 and $1 \mathrm{mS} \mathrm{cm}^{-1}$.

The experimental design adopted was entirely randomized (DIC), with five treatments in relation to water replacement $(40,60,80,100$, and $120 \%$ of the vessel water holding capacity - WHC) and sixteen repetitions for each treatment, totaling eighty vessels, with each vessel considered an experimental unit (EU).

The water holding capacity (WHC) was determined according to the methodology described by Kämpf et al. (2006). Equation 1 described by Mello (2006) and adapted by Schwab et al. (2013) was used to apply the treatments.

$$
M V \%=(\text { MVcrv }- \text { MVdry }) \cdot C R V \%+M V d r y
$$

where: MV\%: is the mass of the vessel; MVcrv: is the mass at the water holding capacity; MVdry: is the mass of the pot filled with completely dry substrate; and, CRV\%: is the percentage of CRV referring to each treatment.

After each irrigation, the quantification of water storage in the substrate was determined by the water balance method, counting the inflows and outflows of water from the pot. Due to the controlled conditions of the protected environment, the only water input was through irrigation performed manually at three-day intervals.
The crop evapotranspiration (ETc) was obtained by means of weighing lysimetry and the reference evapotranspiration (ETo) was calculated using six different equations (Table 2).

The reference evapotranspiration was estimated by different equations seeking to reduce the variation of the estimate by existing methodologies, increasing the reliability of the results. The meteorological variables needed to calculate ETo were measured inside the protected environment. The crop coefficients $(\mathrm{Kc})$ were obtained through the relationship between the ETc estimated by weighing lysimeter and the ETo estimated by different equations (Equation 8).

$$
\mathrm{Kc}=\frac{\mathrm{ETc}}{\mathrm{ETo}}
$$

where: Kc: is the crop coefficient for pot chrysanthemum; ETo: is the reference evapotranspiration $\left(\mathrm{mm} \mathrm{day}^{-1}\right)$; and, ETc: is the crop evapotranspiration $\left(\mathrm{mm} \mathrm{day}^{-1}\right)$.

When the crop was at the point of commercialization $(50 \%$ of the inflorescences open), the number of inflorescences per plant was counted in all treatments evaluated.

The water use efficiency (WUE) was determined by Equation 9, relating the number of inflorescences per plant (NI) and the total amount of water applied during the crop cycle (ETC).

$$
\mathrm{EUA}=\frac{\mathrm{NI}}{\mathrm{ETc}}
$$

where: EUA: is the water use efficiency (inf $\mathrm{mm}^{-1}$ ); $\mathrm{NI}$ : is the number of inflorescence per plant; and, ETc: is the crop evapotranspiration ( $\mathrm{mm} \mathrm{cycle}^{-1}$ ).

The data from the experiment were submitted to variance analysis at a $5 \%$ probability level of error and, if a significant effect was obtained, subsequent regression. For this, the

\begin{tabular}{|c|c|c|c|}
\hline Equation & Abbreviation & Equation & References \\
\hline 2 & $\mathrm{ETO}_{\mathrm{BL}}$ & $\mathrm{ETO}_{\mathrm{BL}}=1.21 \times 10\left(\frac{7.45 \times \mathrm{T}_{\text {med }}}{234.7+\mathrm{T}_{\text {med }}}\right)\left(1-0.01 \times \mathrm{UR}_{\text {med }}\right)+0.21 \times \mathrm{T}_{\text {med }}-2.30$ & Benevides \& Lopez (1970) \\
\hline 3 & ETOCA $_{\text {CA }}$ & $E O_{C A}=K \times R_{a} \times T_{\text {med }} \times N D$ & Camargo (1971) \\
\hline 5 & ETOJH $_{\mu}$ & $\mathrm{ETo}_{\mathrm{JH}}=\mathrm{R}_{\mathrm{S}} \times\left(0.025 \times \mathrm{T}_{\text {med }}+0.078\right)$ & Jensen \& Haise (1963) \\
\hline
\end{tabular}
statistical software SISVAR 5.6 (Ferreira, 2011) was used.

Table 2. Equations for estimating reference evapotranspiration used in the work.

$\mathrm{T}_{\text {me }}$ - average daily temperature $\left({ }^{\circ} \mathrm{C}\right) ; \mathrm{RH}_{\text {me }}$ - average daily relative humidity (\%); $\mathrm{K}$ - adjustment factor that varies with the average annual temperature (o $\mathrm{C}$ ) of the site; $\mathrm{R}$ extraterrestrial solar radiation ( $\left.\mathrm{MJ} \mathrm{m}^{-2} \mathrm{dia}^{-1}\right) ; \mathrm{ND}$ - number of days in the period; $\mathrm{T}_{\mathrm{m}}$ corresponds to $\mathrm{T}_{\text {med }}+0.006 \mathrm{z} ; \mathrm{z}-$ altitude $(\mathrm{m}) ; \mathrm{T}_{\mathrm{d}}$ - dew point temperature $\left({ }^{\circ} \mathrm{C}\right) ; \phi-$ local latitude $\left({ }^{\circ}\right)$; $\mathrm{R}_{\mathrm{s}}$ - global solar radiation converted into units of evaporated water $(\mathrm{mm}) .{ }^{*}$ Ivanov equation described by Jensen (1973). 


\section{Results and Discussion}

According to the results obtained in this work, there was a significant effect for number of inflorescences per plant (NI) and no significant difference was observed for water use efficiency (WUE) among the treatments in the experiment (Table 3).

The results obtained for EUA, corroborate those described by Soares et al. (2015), who working with three cultivars of Kalanchoe grown in a protected environment under distinct irrigation slopes based on different pot capacities $(40,60,80$ and $100 \%$ ), observed no statistically significant differences for the interaction cultivar and irrigation slopes for water use efficiency for flower production per pot.

In turn, Rego et al. (2009), studying the response of different irrigation managements based on the evaporation of the class " $\mathrm{A}$ " tank on cut chrysanthemum grown in a protected environment, reported that as the irrigation rates were increased, the water use efficiency decreased significantly.

The number of inflorescences per plant and the crop water consumption are shown in Figures $2 \mathrm{~A}$ and $2 \mathrm{~B}$, respectively.

It can be seen in Figure $2 \mathrm{~A}$, that the plants subjected to the treatments with higher CRV $(80,100$ and $120 \%)$, presented the highest number of inflorescences in relation to the other treatments. This may have possibly occurred due to the adequate water supply, which allowed the plants to remain physiologically more active, leading to a higher number of inflorescences per plant compared to the treatments with lower water availability.

Exposure of plants to low soil moisture levels causes them to seek mechanisms for their survival, which may adversely impact photoassimilate accumulation and may affect plant production and commercial quality (Soares et al., 2019).

The result found in this work corroborates the one described by Spadeto (2016), who studying the soil water deficit factor at different times after transplanting for cut chrysanthemum cultivar "Faroe", observed a reduction in the production of floral buds as a function of increasing soil water deficit.

Similar results to those found in this experiment were also described by Pereira et al. (2009) who, studying the growth and production of gladiolus under different levels of water deficit, obtained better results regarding the number of flowers in treatments without water deficit. In this sense, Girardi et al. (2016) working with the culture of Alstroemeria, in a protected environment, subjected to different water retention capacities by the pot, verified a greater number of floral stems in treatments with higher water availability. The authors justified this increase in the production of floral stems

Table 3. Analysis of variance for number of inflorescences per plant and water use efficiency for the study treatments.

\begin{tabular}{ccccc}
\hline FV & SQ & QM & F valor & Prob > F \\
\hline NI & 930.1122 & 232.528 & 15.997 & $0.000^{*}$ \\
EUA & 0.004991 & 0.001248 & 3.6590 & $0.0285^{\text {ns }}$ \\
\hline
\end{tabular}

* Significant at $5 \%$ probability of error; $\left({ }^{n s}\right)=$ not significant at $5 \%$ probability of error.

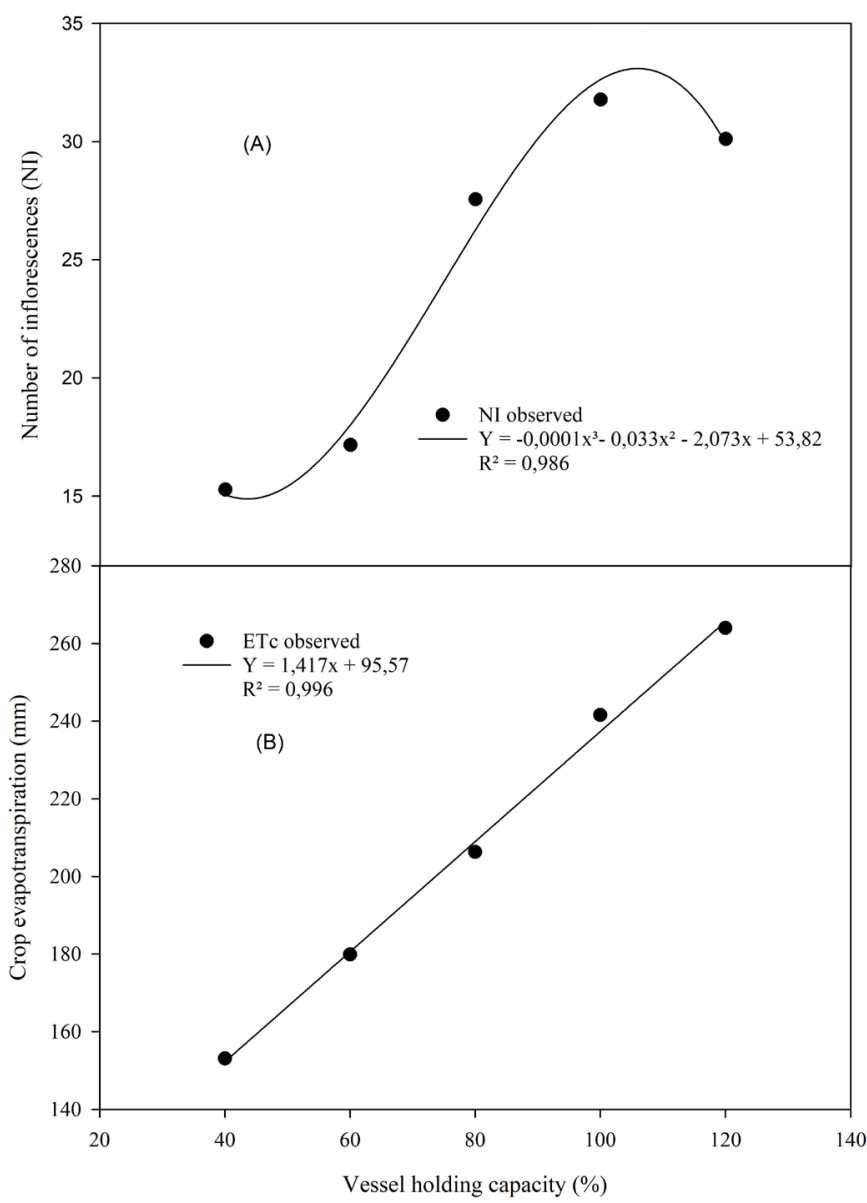

Figure 2. Number of inflorescences per plant $(A)$ and cumulative crop evapotranspiration (ETC) (B) for the study treatments.

by the action of water in the plant cells, where with adequate water availability, the processes of turgor and cell growth are favored, resulting in plant development, expansion, cell division, and photosynthesis. And, further Piroli (2018) describes better development and production results for cut gerbera when grown in the range of 80 to $100 \%$ of the water holding capacity in the pot.

As seen in Figure 2B, the potted species showed a linear response for crop evapotranspiration at the different pot capacities. It is noteworthy that the 40 and $120 \%$ CRV treatments showed lower and higher water consumption by the crop, respectively. This behavior of increased consumption in treatments with higher water availability, was also described by Girardi et al. (2016), Soares et al. (2019) and by Piroli et al. (2020), in studies with Alstroemeria, cravina and gerbera, respectively, grown in a protected environment and conducted under different water retention capacities by the pot.

The increasing water consumption with increasing water holding capacity can be explained by the increased evaporation of water from the substrate and the increased transpirative demand of the crop. According to Girardi et al. (2016), when the water conditions of the pot are maintained at maximum water holding capacity by the pot, water moves more easily, 
and there is no impediment for transpiration by the plants and likewise, for evaporation of the water contained in the substrate, causing greater water consumption.

The estimated average daily reference evapotranspiration for the different equations used, as well as the average crop evapotranspiration for each crop development stage, is presented in Figure 3. We considered as crop evapotranspiration the blade coming from the treatment of $80 \%$ of CRV (206 mm), because no significant difference was found for water use efficiency between treatments, nor for inflorescence production between the treatments of 80,100 and $120 \%$ of CRV, so we opted for the lowest value of response blade ( $80 \%$ of CRV).

The pot chrysanthemum culture does not have a standard phenological scale described in the scientific literature, so the cycle of the culture was divided into five phases according to its phenological development, and in virtue of the regularity of water consumption of each phase. Thus, the first phase was defined as from the beginning to the middle of the vegetative phase (VEG 1), the second, from the middle to the end of the vegetative phase (VEG 2), the third phase corresponding to the formation of inflorescences (FL1), the fourth phase when $50 \%$ of the inflorescences were open, that is, the point of commercialization (FL2) and, finally, from the opening of $100 \%$ of the inflorescences (PFC).

In general, it is observed that the reference evapotranspiration estimated by the different equations was higher than the crop water consumption until the middle of the vegetative phase, because in this phase the leaf area is still small and the transpiration rate is still low. From the middle to the end of the vegetative phase the estimated evapotranspiration was lower than the crop evapotranspiration. However, the reference evapotranspiration estimated by the Camargo

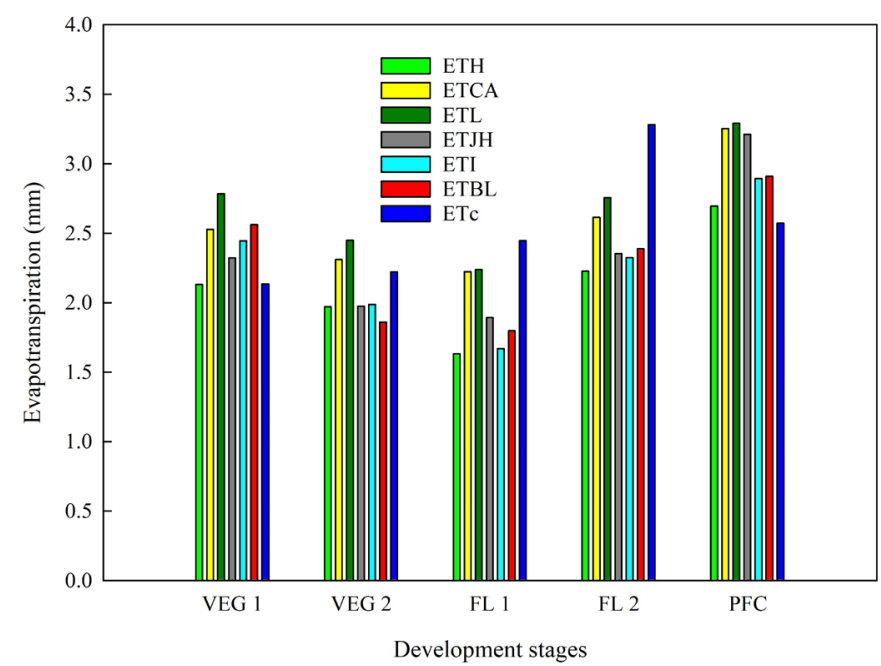

ETH: reference evapotranspiration estimated by the Hargreaves equation; ETCA: reference evapotranspiration estimated by the Camargo equation; ETL: reference evapotranspiration estimated by the Linacre equation; ETJH: reference evapotranspiration estimated by the Jensen-Haise equation; ETI: reference evapotranspiration estimated by the Ivanov equation; ETBL: reference evapotranspiration estimated by the BenevidesLopez equation; ETc: the crop evapotranspiration measured by lysimetry.

Figure 3. Reference evapotranspiration estimated by different equations and the crop evapotranspiration along the crop cycle. and Linacre equations showed higher values than the crop evapotranspiration from the middle to the end of the vegetative stage.

The difference between the estimated ETo values by the different equations is justified by the fact that the calculation parameters differ among the equations in the study and use different input data in the ETo estimation calculation.

In the reproductive phase the crop evapotranspiration was higher than the reference evapotranspiration estimated by the equations until the PFC phase, where the water consumption decreased due to the closure of the crop production cycle.

The consumption data are in agreement with those obtained by Pereira et al. (2005), who, in a study aimed at determining the water consumption of two cultivars of cut chrysanthemum, verified that the consumption is dependent on the phase that the culture is in, and is not constant throughout the cycle.

It is observed that the highest consumption occurred when the crop was forming its inflorescences, because in this phase the plant has an accelerated metabolism, demanding a greater nutritional and water contribution. The same behavior was reported by Girardi et al. (2016), who observed in the formation of Alstroemeria flowers, in the transition from the vegetative to the reproductive stage, an increase in crop transpiration by physiological development, causing an increase in plant water consumption.

Considering the crop evapotranspiration and the different estimated reference evapotranspirations, the respective crop coefficients were obtained (Table 4) for the phases established in the study for the chrysanthemum cultivar Cherry White.

It can be seen that the values of the crop coefficients are increasing as the crop develops until the FL2 phase, where they reach their apex with an average value for the different $\mathrm{Kc}$ values of 1.33 . Subsequently, due to a reduction in the crop's water demand, a decrease in Kc values occurs. This behavior is in agreement with that described by Allen et al. (2006), who reported that the Kc is variable depending on the phenological stage of the crop and may reach its highest value in the reproductive phase of many crops, which was observed in this study.

In the vegetative phase an average $\mathrm{Kc}$ for the different equations of 0.98 was obtained, and for the reproductive phase an average Kc of 1.14 was found. Similar results were described by Piroli et al. (2020), for the culture of cut gerbera conducted in a protected environment, finding $\mathrm{Kc}$ values of 0.76 and 1.03 , respectively for the vegetative and reproductive phase.

In work with cut roses, conducted in a protected environment, Oliveira et al. (2014), obtained Kc values of 0.75 for the vegetative phase and 1.18 for the productive phase of the crop. Similar results to those found in the present study, under protected environment conditions, were also described by Felisberto et al. (2015), for the culture of Heliconia Gonden Torch, obtaining values of 0.80 and 1.01 respectively, for the 
Table 4. Crop coefficients calculated for the different reference evapotranspiration estimation methodologies as a function of the development stage of pot chrysanthemum.

\begin{tabular}{|c|c|c|c|c|c|c|c|c|c|}
\hline \multirow{2}{*}{ DAT } & \multirow{2}{*}{ PHASE } & \multicolumn{6}{|c|}{ Kc } & \multirow{2}{*}{$\begin{array}{c}\text { Amplitude } \\
\text { Kc }\end{array}$} & \multirow{2}{*}{$\begin{array}{c}\text { ETc } \\
\left(\mathrm{mm} \mathrm{day}^{-1}\right)\end{array}$} \\
\hline & & Hargreaves & Camargo & Linacre & Jensen Haise & Ivanov & Benevides Lopez & & \\
\hline $31-44$ & VEG 1 & 1.00 & 0.89 & 0.81 & 0.92 & 0.99 & 0.94 & 0.19 & 2.13 \\
\hline $45-59$ & VEG 2 & 1.13 & 0.96 & 0.91 & 1.15 & 1.12 & 1.00 & 0.24 & 2.22 \\
\hline $60-82$ & FL 1 & 1.22 & 1.16 & 1.13 & 1.27 & 1.38 & 1.26 & 0.25 & 2.45 \\
\hline $83-98$ & FL 2 & 1.47 & 1.25 & 1.20 & 1.32 & 1.40 & 1.37 & 0.27 & 3.28 \\
\hline $99-108$ & PFC & 0.93 & 0.79 & 0.78 & 0.80 & 0.89 & 0.88 & 0.15 & 2.57 \\
\hline
\end{tabular}

DAT: days after transplanting; Kc: cultural coefficient; ETc: average daily crop evapotranspiration; VEG1: beginning to the middle of the vegetative phase; VEG2: half by the end of the vegetative phase; FL1: formation of inflorescences; FL2: 50\% open inflorescences; PFC: $100 \%$ open inflorescences.

vegetative and reproductive phases, and by Gomes et al. (2008) who observed for the culture of Alpinia, average values of 0.72 for vegetative phase and 1.07 for reproductive phase.

As highlighted by Oliveira et al. (2014), scientific studies are scarce regarding crop coefficients for ornamental plants and the available values are quite discrepant, which makes it difficult to compare crop coefficients. This variability can be explained by the fact that Kc changes according to variety, soil type and coverage, irrigation system, crop management, and ETo estimation adopted (Duarte et al., 2010).

The range of Kc values obtained in this study was relatively low ( $>0.27)$, so it can be said that the different equations for estimating ETo tested can be used to estimate ETo in a protected environment.

\section{Conclusions}

The crop water consumption was increasing with increasing pot water availability. The evapotranspiration of pot chrysanthemum varied between 153 and $264 \mathrm{~mm}$ in the different treatments tested.

There was no significant difference between the water use efficiency for the different irrigation managements adopted in the experiment, the overall average water use efficiency value for the experiment was $0.115 \mathrm{inf} \mathrm{mm}^{-1}$.

The average crop coefficients estimated for the chrysanthemum cultivar 'Cherie White', were 0.98 for vegetative phase and 1.29 from the beginning of the reproductive phase until the point of commercialization and then 0.85 until the end of the reproductive phase.

\section{Compliance with Ethical Standards}

Author contributions: Conceptualization: ACP, MXP, MAR, ADR; Data curation: ACP; Formal analysis: ACP, JDP, LDF, JHK, WM; Funding acquisition: ACP, MXP, MAR, ADR; Investigation: ACP, JDP, LDF, JHK, WM; Methodology: ACP, MXP, MAR, ADR; Project administration: ACP, MXP, MAR, ADR; Resources: ACP, JDP, LDF, WM; Supervision: MXP, MAR, ADR; Validation: ACP, $M X P, M A R, A D R$; Visualization: ACP; Writing - original draft: $A C P$; Writing - review \& editing: $A C P, M X P, M A R, A D R$.

Conflict of interest: The authors declare no conflict of interest.

Financing source: Coordenação de Aperfeiçoamento de Pessoal de Nível Superior (CAPES) - Finance Code 001.

\section{Literature Cited}

Allen, R. G.; Pereira, L. S.; Raes, D.; Smith, M. Evapotranspiración del cultivo: guias para la determinación de los requerimentos de água de los cultivos. Rome: FAO, 2006. 298p. (Estudio FAO Riego y Drenaje, 56). http://www.fao.org/3/x0490s/x0490s.pdf. 02 Aug. 2020.

Andrade, A. D.; Miranda, W. L., Carvalho, L. G. de.; Figueiredo, P. H. F.; Silva, T. B. S. da. Desempenho de métodos de cálculo do coeficiente de tanque para estimativa da evapotranspiração de referência. Revista Irriga, v. 21, n. 1, p. 119-130, 2016. https:// doi.org/10.15809/irriga.2016v21n1p119-130.

Barbosa, J.G.; Saraiva, J.A.; Borém, G.A. Crisântemo: do plantio à colheita. Viçosa: Editora UFV; CEAD, 2019. 136p.

Benevides, J. G.; Lopez, D. Formula para el cálculo de la evapotranspiración potencial adaptada al trópico (15ㅇN - 15으) S). Agronomia Tropical, v. 20, n. 5, p. 335-345, 1970.

Camargo, A. P. Balanço hídrico no estado de São Paulo. 3.ed. Campinas: IAC, 1971. 24 p. (Boletim IAC, n. 116).

Comissão de Química e Fertilidade do Solo - CQFS. Manual de calagem e adubação para os Estados de Rio Grande do Sul e de Santa Catarina. Viçosa: Sociedade Brasileira de Ciência do Solo, 2016. 376p.

Duarte, G. R. B.; Schöffel, E. R.; Mendez, M. E. G.; De Paula, V. A. Medida e estimativa da evapotranspiração do tomateiro cultivado sob adubação orgânica em ambiente protegido. Semina: Ciências Agrárias, v. 31, n. 3, p. 563-574, 2010. https:// doi.org/10.5433/1679-0359.2010v31n3p563.

Felisberto, T. da S.; Silva, D. de O.; Souza Filho, J. R. de.; Santos, W. J. dos.; Deon, M. D.; Marinho, L. B. Evapotranspiração e coeficiente de cultivo da helicônia golden torch no Vale do São Francisco. Revista Brasileira de Agricultura Irrigada, v. 9, n. 5, p. 335-343, 2015. https://doi.org/10.7127/rbai.v9n500331.

Ferreira, D. F. Sisvar: a computer statistical analysis system. Ciência e Agrotecnologia, v. 35, n. 6, p. 1039-1042, 2011.https://doi. org/10.1590/S1413-70542011000600001.

Girardi, L. B.; Peiter, X. P.; Bellé, R. A.; Robaina, A.D.; Torres, R. R.; Kirchner, J. H.; Ben, L. H B. Evapotranspiração e coeficiente de cultura da alstroemeria (Alstroemeria $x$ hybrida) cultivada em estufa. Revista Irriga, v. 21, n. 4, p. 817-829, 2016. https://doi. org/10.15809/irriga.2016v21n4p817-829.

Gomes, A. R. M.; Gondim, R. S.; Bezerra, F. C.; Costa, C. A. G. Evapotranspiração e coeficientes de cultivo da Alpinia purpurata. Revista Ciência Agronômica, v.39, n. 4, p.481-486, 2008. http:// ccarevista.ufc.br/seer/index.php/ccarevista/article/view/211. 27 Apr. 2020. 
Hargreaves, G. H. Estimation of potential and crop evapotranspiration. Transactions of the ASAE, v.17, n.4, p.701-704, 1974. https://doi. org/10.13031/2013.36941.

Heldwein, A. B.; Buriol, G. A.; Streck, N. A. O clima de Santa Maria. Ciência \& Ambiente, v.38, n.1, p.43-58, 2009.

Instituto Brasileiro de Floricultura - Ibraflor. Mercado de flores. https://www.ibraflor.com.br/. 13 May. 2020.

Jensen, M. E. Consumptive use of water and irrigation water requirements. New York: American Society of Civil Engineers, 1973. 215p.

Jensen, M. E.; Haise, H. R. Estimating evapotranspiration from solar radiation. Journal of the Irrigation and Drainage Division, v. 89, n. 4, p. 15-41, 1963. https://doi.org/10.1061/JRCEA4.0000287.

Kämpf, A. N; Takane, R. J.; Siqueira, P. T. V. Floricultura: técnicas de preparo de substratos. Porto Alegre: LK, 2006. 132p. (Tecnologia fácil, 19).

Kelling, C. R. S., Reichardt, K., Streck, N. A., Lago, I., Zanon, A. J., Rodrigues, M. A. Transpiração e crescimento foliar de crisântemo em função da fração de água transpirável no substrato. Pesquisa Agropecuária Brasileira, v. 50, n. 9, p. 735-744, 2015. https://doi. org/10.1590/S0100-204X2015000900001.

Linacre, E.T. A simple formula for estimating evaporation rates in various climates, using temperature data alone. Agricultural Meteorology, v.18, n.6, p.409-24, 1977. https://doi. org/10.1016/0002-1571(77)90007-3.

Mello, R. P. Consumo de água do lírio asiático em vaso com diferentes substratos. Santa Maria: Universidade Federal de Santa Maria, 2006. 74p. Master's Dissertation. http://repositorio.ufsm.br/ handle/1/7490. 22 Jun. 2020.

Oliveira, E. C., Carvalho, J. A., Almeida, E. F. A., Rezende, F. C., Reis, S. N., Mimura, S. N. Rendimento de rosas cultivadas em ambiente protegido sob diferentes níveis de irrigação. Irriga, v.21, n.1, p.1424, 2016. https://doi.org/10.15809/irriga.2016v21n1p14-24.

Oliveira, E. C.; Carvalho, J. A.; Rezende, F. C.; Almeida, E. F. A.; Reis, S. N.; Mimura, S. N. Evapotranspiração da roseira cultivada em ambiente protegido. Revista Brasileira de Engenharia Agrícola e Ambiental, v. 18, n. 3, p. 314-321, 2014. https://doi.org/10.1590/ S1415-43662014000300011.

Oliveira, E.C. Irrigação da roseira cultivada em sistema de produção integrada: viabilidade técnica e econômica. Lavras: Universidade Federal de Lavras, 2012.186p. Doctoral Thesis. http://repositorio. ufla.br/jspui/handle/1/605. 22 Jun. 2020.

Oliveira, G. M. DE; Santiago, E. J. P.; Leitão, M. DE M. V. B. R.; Rocha, R. de C.; Gonçalves, I. S.; Silva, R. R. da. Estimativa da evapotranspiração de referência para ambiente protegido. Irriga, v.1, n.1, edição especial, p.21-30, 2017. https://doi. org/10.15809/irriga.2017v1n1p21-30.
Pereira, J. R. D.; Carvalho, J. A.; Miguel, D. S.; Santana, M. J. Consumo de água pela cultura do crisântemo cultivado em ambiente protegido. Engenharia Agrícola, v. 25, n. 3, p. 651-659, 2005. https://doi.org/10.1590/S0100-69162005000300010.

Pereira, J. R. D.; Carvalho, J. A.; Paiva, P. D. O.; Silva, D. J.; Souza, A. M. G.; Souza, K. J. S. Crescimento e produção de hastes florais de gladíolo cultivado sob diferentes tensões de água no solo. Ciência e Agrotecnologia, v. 33, n. 4, p. 965-970, 2009. https:// doi.org/10.1590/S1413-70542009000400004.

Piroli, J. D. Produção de gérbera de corte (Gerbera jamesonii) em função de diferentes disponibilidades hídricas. Santa Maria: Universidade Federal de Santa Maria, 2018.71p. Master's Dissertation. http:// repositorio.ufsm.br/handle/1/13822. 02 Aug. 2020.

Piroli, J.D.; Peiter, M.X.; Robaina, A.D.; Rodrigues, M.A.; Ferreira, L.D.; Bortolás, F.A.; Rodrigues, S.A.; Bruning, J. Crop coefficient of cut gerbera with water supplementation in a protected environment. Revista Brasilieira de Ciências Agrárias, v.15, n.1, e7652, 2020. https://doi.org/10.5039/agraria.v15i1a7652

Rego, J. de L.; Viana, T.V. de A.; Azevedo; B.M. de; Araújo, W.F.; Furlan, R.A.; Bastos, F.G.C. Produtividade de crisântemo em função de níveis de irrigação. Horticultura Brasileira, v.27, n.1, p.45-48, 2009. https://doi.org/10.1590/S0102-05362009000100009.

Schwab, N. T.; Peiter, M. X.; Bellé, R. A.; Backes, F. A. A.; Robaina, A. D.; Ferraz, R. C. Consumo hídrico de cravina submetida a diferentes estratégias de irrigação e tamanhos de vaso. Revista Irriga, v. 18, n. 2, p. 328-336, 2013. https://doi.org/10.15809/ irriga.2013v18n2p328.

Soares, F. C., Parizi, A. R., Corrêa, F. R., Bortolás, F. A., Pinheiro, G. L., Rosa, V.P,Russi, J. L. Efeito da dotação de rega em cultivares de Kalanchoe blossfeldiana. Revista de Ciências Agrárias, v. 38, n. 1, p. 41-48, 2015. http://www.scielo.mec.pt/scielo.php?script=sci_ arttext\&pid=S0871-018X2015000100007. 28 Apr.2020.

Soares, F. C.; Mello, R. P.; Peiter, M. X.; Bellé, R. A.; Robaina, A. D.; Vivan, G. A.; Parizi, A.R. Consumo de água pela cultura do lírio, cultivado em substratos alternativos em condições de ambiente protegido. Revista Ciência Rural, v. 42, n. 6, p. 1001-1006, 2012. https://doi.org/10.1590/S0103-84782012000600008.

Soares, F. C.; Netto, J. F.; Russi, J. L.; Duran, C. B.; Bortolás, F. A.; Lira, P. da Rosa.Consumo hídrico, crescimento e desenvolvimento da cultivar Dianthus chinensis L. submetida a diferentes doses de irrigação. Brazilian Journal of Development, v.5, n.6, p.67196728, 2019. https://doi.org/10.34117/bjdv5n6-165.

Spadeto, M. F. Desenvolvimento e produção de crisântemo submetido a diferentes níveis de déficit hídrico no solo. Alegre: Universidade Federal do Espírito Santo, 2016. 60p. Master's Dissertation. http://portais4.ufes.br/posgrad/teses/tese_8427_ Marjorie\%20Freitas\%20Spadeto.pdf. 22 Jun. 2020. 